Aletria, Belo Horizonte, v. 27, n. 2, p. 113-126, 2017

\title{
Tessituras dramatúrgicas: a imagem como escritura performática
}

\section{Dramaturgic Textures: the Image as Performative Writing}

\author{
Eder Rodrigues \\ Pesquisador \\ ederdelrodrigues.literatura@gmail.com
}

Resumo: Este artigo se concentra nos estudos sobre dramaturgia contemporânea e no diálogo interartes como motor de sua tessitura. A fronteira entre as artes e as perspectivas de trabalho com o texto na cena atual são investigadas a partir do labor que elege a imagem como o fundamento de suas fontes, teorizações e adjacências. As questões levantadas analisam o prospecto da imagem enquanto escritura performática e também como correspondente de um pensamento pautado sobre o imagético como dispositivo político e estético. Nesta vertente, apresento o trabalho do dramaturgo português Mickaël de Oliveira junto ao Colectivo 84 para sublinhar o viés conceitual pautado em um olhar plural sobre o texto em relação às fontes tradicionais de produção, além de evidenciar o performático de sua gênese.

Palavras-chave: dramaturgia; imagens; Mickaël de Oliveira, performance.

Abstract: This article focuses on contemporary dramaturgy in its dialogues with other arts. I investigated the boundaries between the arts and the perspectives on the theatrical text in the current scene, considering especially the uses of the image as the foundation ot its sources and methods, and fostering a discussion about the text and its adjacencies. I analyse the view of the image both as performative writing and as corresponding to a form of thinking based on the imagery as an aesthetic and political device. Along these lines, I discuss the work of the Portuguese playwright Mickaell de Oliveira and his collaboration with Colective 84 to highlight this conceptual work based on a plural view about the text in relation to the traditional sources of production, and to demonstrate how it is rooted in performance.

Keywords: dramaturgy; images; Mickaël de Oliveira, performance. 
Os enfoques teóricos dos últimos decênios em torno da dramaturgia argumentam sobre o espaço de experiência que este tipo de escritura efetiva, sublinhando principalmente os desdobramentos que sua processualidade desencadeia no corpus textual. Esta frente de estudos amplia as discussões que envolvem a fronteira entre as artes perante essa modalidade, que se debruça sobre a escrita em suas fontes ou domínios performáticos.

A topografia deste pensamento, que surge após a fusão dos princípios e práticas performáticas e dramatúrgicas, ${ }^{1}$ aponta para $\mathrm{o}$ redimensionamento da palavra "texto" nas poéticas contemporâneas, que passam a incorporar todos os elementos pertencentes à engrenagem teatral como tessituras complementares e heterogêneas. As zonas de deslocamento entre a palavra e a imagem passam a constituir um espaço fluido que mobiliza outras instâncias de construção escritural.

A escrita para o teatro possuiu especificidades que a distingue de forma determinante de outros gêneros. $\mathrm{O}$ simples fato de escrever, sabendo que a consolidação desse ato só se efetiva com o desdobramento do material textual em cena, já torna a dramaturgia um veículo instigante em que os universos da palavra e do palco se relacionam de maneira específica. No teatro, o ato da escrita, seja ela precedente à cena ou em processo, pressupõe uma perspectiva diferenciada de sua concretude, uma vez que o exercício escritural prevê a experiência do palco como condição sumária para que o repertório dessa materialidade se efetive, fato que distingue seus princípios desde os estágios preliminares da elaboração.

O destaque que a palavra "dramaturgia" tem ganhado ultimamente não se deve apenas à emblemática ponte que se constrói entre o universo da palavra e o do palco, mas também a uma rede de saberes que se agregou ao âmbito deste termo, construindo distintas formas de se exercitar o papel de dramaturgo ao longo da historiografia teatral. No cenário contemporâneo, o rol de discussões salta do eixo paradoxal que, recorrentemente, polariza as discussões em torno dos debates entre a dramaturgia e a literatura, ${ }^{2}$ para um terreno onde a práxis protagoniza os

\footnotetext{
${ }^{1}$ Esta fusão pode ser lida como fruto oriundo da gênese vivenciada junto às criações coletivas e, posteriormente, com os processos colaborativos.

${ }^{2}$ Refiro-me às discussões que se atêm à literariedade e à teatralidade de determinado texto como características que se contrapõem, ou seja, as vertentes literárias que desprezam o peso dramatúrgico da literatura dramática e os estudos teatrais que pormenorizam o
} 
embates. Este salto traz consigo inúmeras questões, das quais podemos destacar: a complexa junção das linguagens utilizadas para a composição da materialidade que se torna o substrato de um espetáculo, os processos de criação e seus distintos pontos de partida e fluxos de chegada e as relações pluridimensionais que o texto adquire em sua gênese laboral.

$\mathrm{Se}$, tradicionalmente, o teatro ocidental interligou a figura do dramaturgo ao profissional responsável pela escrita dos textos que serviam de matriz para a cena, cuja função dos demais profissionais era a de ilustrá-lo cenicamente, torna-se preponderante o fato de que a evolução técnica pela qual passou o teatro na segunda metade do século XIX, e que culminou com o advento da figura do encenador no século $\mathrm{XX}$, acaba por contrapor esta supremacia. Se, durante muito tempo, numa perspectiva ortodoxa, os textos teatrais foram fundamentalmente escritos sob a égide dos preceitos aristotélicos, que garantiam a sua eficiência (com a palavra sendo o eixo de sua operacionalidade), também se percebe que, a partir do momento que os outros elementos cênicos ${ }^{3}$ ganham equidade e autonomia, impactos provindos da ampliação desse status modificarão as formas de se pensar o teatro e, consequentemente, o ofício encarregado de suas tessituras.

Os dramaturgos não ficaram alheios às modificações do espetáculo contemporâneo e parecem ter incorporado ao veículo literário os procedimentos criados por seus parceiros de cena, redefinindo assim os limites da textualidade dramática. ${ }^{4}$

Cada vez mais, torna-se perceptível uma preocupação em se permear com mais nitidez os arredores do ofício dramatúrgico, explorando os princípios metodológicos em que suas ações acontecem. Isso nos leva a investigar outras texturas e textualidades, entendendo o texto em outra esfera (como algo vivo, referencial, presencialmente escrito), aberto ao diálogo com as outras artes e, sobretudo, sensível às novas formas de

status literário das peças, esforços que não lançam um olhar complementar sobre estes polos, restringindo as fronteiras tanto de um quanto de outro.

${ }^{3}$ Elementos como a iluminação, o espaço, o universo plástico e até as técnicas de atuação que conhecem na transição dos séculos XIX para o XX uma escala nítida de aperfeiçoamentos inseridos, basicamente, na corrente artística que buscava um Novo Teatro mais condizente com o contexto emergente e seus anseios.

${ }^{4}$ FERNANDES. Teatralidades contemporâneas, p. 157. 
escritura que o teatro explora. Este olhar reascende as discussões sobre o tema, atribuindo peso teórico ao processo de criação, uma vez que a pluralidade de seus registros requer prerrogativas que trabalhem com a extensão do conceito de "texto", com as designações transmidiáticas e com o formato performático da escritura. Esta demanda também se alicerça nos aspectos críticos associados aos Estudos Interartes, inserindo o texto teatral em um referencial que explora a sua pluralidade constitutiva e significativa, num cenário em que a dramaturgia se encontra, justamente, no campo onde as fronteiras são abolidas.

A primeira metade do século XX, assiste a transposição em que ocorre a autonomia da imagem em relação à palavra e ao mimetismo representacional. Assim como outras áreas do teatro, a dramaturgia assimilou contextos e impactos, agregou e subtraiu elementos de sua gênese, individualizou e coletivizou seus eixos funcionais de acordo com as exigências do palco, fatos comprovadores de que, paralelamente às transformações sofridas no campo da atuação, da encenação e da plasticidade, os modos de escritura também se modificaram de forma determinante.

A apropriação de elementos heterogêneos e a transformação dos mesmos, segundo uma leitura híbrida de constituição, é possível de ser observada em práticas culturais ao longo da história da literatura, porém, na década de 1920 do século passado, junto aos movimentos vanguardistas, é que esta prerrogativa se evidencia enquanto proposta estrutural. Nessa mesma época, os paradigmas que norteiam a área teatral passam pelos reflexos do movimento simbolista que, no teatro, aliados aos recursos da iluminação de matriz elétrica (só inserida na arquitetura teatral no final do século XIX) acabam propulsionando uma cisão na base da concepção teatral, substituindo o textocentrismo tradicional por uma preocupação plástica e visual da encenação.

A partir desta nova perspectiva, o encenador passa a construir um discurso autônomo em relação ao texto dramático. $O$ teatro passa a ser escrito numa esfera espetacular, outorgando abrangência e autonomia aos diversos elementos da linguagem cênica, propiciando a utilização da intertextualidade, da colagem e de outros recursos que se proliferam na segunda metade do século XX, ancorados principalmente na imagem como o substrato de novas tessituras. As experiências coletivas de criação dramatúrgica, propulsionadas pelo advento da performance, introduzem outras referências no seu modus operandi, estabelecendo uma 
reconfiguração do ofício, na medida em que se retroalimentam labores performáticos e corpus dramatúrgico. Os processos colaborativos, que ganham a sala de ensaios dos grupos no final do século XX, amplificam esta perspectiva, já que os campos se atravessam juntos a uma tessitura partilhada de todas as engrenagens que movem o espetáculo, abertura capaz de eleger outros fundamentos dramatúrgicos como estruturadores dos preceitos estéticos e políticos do trabalho, tais como a dialética das imagens produzidas pelo corpus atoral.

Esta prerrogativa que entende a dramaturgia como uma arte ligada ao universo relacional, cujas ações, criadas e estabelecidas na gênese criativa, constituem tramas complexas, faz parte dos princípios de trabalho do dramaturgo e pesquisador português Mickäel de Oliveira. Seu trabalho na cena contemporânea se debruça sobre a dramaturgia e seus processos, além de difundir um pensamento que reconhece novas instâncias para o labor criativo envolvendo os profissionais da cena no século XXI. O dramaturgo escreve para o teatro desde 2004, sendo o cofundador do Colectivo 84. Junto a este grupo, escreveu um conjunto de peças que cria zonas de tensão entre as raízes do dramático e a performatividade, oriunda de fontes diversas, ao esfacelar os princípios aristotélicos, tendo como prerrogativas os diálogos estéticos entre dramaturgia e encenação. No ano de 2015, teve cinco de seus textos reunidos na edição Obra completa (2006-2014), publicada pela Editora Humus.

O entendimento de Oliveira fortalece os propósitos de que as relações tecidas no âmbito da cena é que promovem o objeto da circunscrição dramatúrgica, ato em que as textualizações proeminentes geram correspondentes no tempo e no espaço em que a imagem passa a ser o seu correspondente mais direto. Os vetores acionados nas construções que envolvem a imagem não são basicamente estruturados pelo viés significante/significado. A imagem quando utilizada como dispositivo escritural leva consigo todo o seu contexto originário que dialoga (de forma harmônica ou não) com a nova topografia onde é colocada. Temos nesse trânsito um circuito que se estende pelas relações estabelecidas entre a tessitura e o espectador, já que "do aspecto poético das imagens, desse espaço de resistência e de negociação que está aberto à intervenção daquele que olha, é que dá voz ao sentido cultural que 
todo olhar comporta, como expressão das subjetividades presentes na operação cultural de olhar."5

A escrita teatral, inclusive, pauta-se pela palavra em performance, ou seja, o polo ativo da escrita teatral também pode ser atribuído ao receptor, uma vez que as relações tecidas contam com a presença do espectador nesta rede relacional fluida e contínua, que estabelece em cena uma dinâmica espaçotemporal. Segundo Renato Cohen, "as construções imagéticas também não obedecem a uma gramática discursiva, ao encadeamento e à hierarquização da fala", ${ }^{6}$ fato permissivo à construção de uma linguagem gerativa, ao invés do princípio normativo que obstrui novos formatos ou mesmo caminha para a homogeneização daquilo que, por natureza, é heterogêneo.

Ao se enveredar por uma "poética de imagens", Oliveira inverte a primazia da palavra para explorar os limites e potencialidades da cena que se efetiva ao estruturar uma poética capaz de reunir, numa mesma dramaturgia, universos simbólicos díspares. As imagens circunscrevem um plano dramatúrgico que convoca os espectadores não apenas a uma decodificação segundo o status "significante/significado", mas a um mergulho no além da letra, no universo sonoro, no encadeamento imagético que faz emergir outros terrenos do sentimento, do político e da existência. Este labor passa a ter como horizonte estruturador não o enredo que conduz a trama, mas a rede plural e híbrida que o atravessa.

O processo de absorção e transformação de textos e imagens na cena, além de pluralizar a teatralidade conferida, constrói diálogos até então impossíveis entre as textualidades que a imagem remete e as redes imagéticas que a palavra congratula. Na junção desses aportes, a edificação de uma estrutura se torna poética no sentido de parodiar, contextualizar, estranhar, contrapor, sublinhar e questionar elementos díspares, como é o caso do espetáculo Horror ou breve estudo sobre a paralisia, de 2011, sob a direção de John Romão.

O espetáculo Horror ou breve estudo sobre a paralisia estreou em 9 de junho de 2011, no Teatro Nacional D. Maria, em Lisboa. Dentro do repertório do Colectivo 84, esta montagem pode ser lida como um trabalho em que a performatividade dos materiais reunidos no processo

\footnotetext{
${ }^{5}$ FERRARI; CASTRO. Política e poética das imagens como processos educativos, p. 15 .

${ }^{6}$ COHEN. Work in progress na cena contemporânea, p. 642
} 
fundamenta a estrutura dramatúrgica segmentada por fluxos imagéticos. Este determinante instaura os prospectos performáticos pelos quais o grupo se orienta, construindo uma peça sobre a passagem (in)tensa dos corpos e a crueza das relações estabelecidas num contexto de alarde e ultimatos. O site do grupo faz referência explícita ao corpo como pilar estruturante e estruturador dessa construção:

Horror interroga a capacidade que temos de paralisar a criação de utopias urgentes e de nos tirar o sono, ao revelarnos em excesso, em nome da ideologia do progresso e do lucro, dos mistérios da fé e do corpo. Propomos, em cena, através de corpos trágicos e festivos, uma incursão pela impossibilidade de nos tornarmos ingénuos perante um cenário político e económico decadente. ${ }^{7}$

Inscrita sob uma perspectiva de resistência em relação à globalização e aos ímpetos do consumismo, a peça sublinha a paralisia diante de fatos pontuados como indícios incontornáveis e prenúncios da falência institucional e utópica do século XXI. Numa atmosfera que presentifica o caos na figura de corpos, a construção de camadas plásticas desfila um caleidoscópio de pressas e vícios, evidenciando a coleção contemporânea de urgências tensionadas como fronteira para a imersão na profundidade das coisas. $\mathrm{O}$ ofício da tessitura das cenas incorpora o percurso atoral como veículo dessa contracorrente, desvelando as sociopatias contemporâneas. Na época da estreia, a crítica teatral de Lisboa referenciou essa potencialidade do espetáculo:

Este teatro não é apenas político nem reflete tão só uma inquietação ou dor de crescimento juvenil. É um teatro que intervém contra a corrente. Portanto, uma necessidade primária quando a mudança, afinal, apenas sustenta persistentemente a agonia política e social e espiritual da sociedade. [...] Um louvável acto de guerrilha cultural capaz de chocar. ${ }^{8}$

\footnotetext{
${ }^{7}$ Disponível em: $<$ http://colectivo84.blogspot.com.br $>$. Neste artigo, optei por manter as diferenças ortográficas do português de Portugal, tais como constam nos textos e referências.

${ }^{8}$ MONTEIRO. Crítica: horror ou breve estudo sobre a paralisia.
} 
Na peça, paisagens são construídas e diluídas em meio ao clima vertiginoso da atualidade, criticando e expondo as linhas padronizadas de comportamento cultuadas pela cultura de massa. O motor corpóreo atua como um dispositivo desencadeador dos fluxos dramatúrgicos, exercendo dois vetores nesta construção. Primeiro, em relação à inclusão do corpo como tema numa expectativa em que a sua apropriação, emancipação e reivindicação ganha contornos mais complexos, quando seu protagonismo acentua o aprisionamento das subjetividades em meio às grades da geração do fast-food, do delivery e da imediatez. O corpo, no caso, passa a ser um instrumento simbólico e performático para se falar do país, do peso contemporâneo de se ver diluído nas próprias noções de tempo e espaço que, de tão múltiplas, acabam nos anulando, fator que mensura a dimensão política da peça. Segundo, pela eleição do corpus atoral como a válvula de cada um dos blocos paisagísticos que compõem o enfrentamento desta geração, recorrendo, no caso, aos códigos perfomáticos. "O discurso performativo é um acto no espaço (no visível) e no tempo (no invisível), como tal, é no cruzamento de ambos os eixos que o espectáculo ganha terreno ontológico: existe, dizendo-se e fazendo-se."

Nesse sentido, a matriz dramatúrgica se desloca da palavra para o corpo, dialogando novas formas que surgem a partir deste referencial performático que pressupõe outros fundamentos para sua construção. $\mathrm{O}$ corpo ganha um tom de manifesto e o ciclo de movimentações e relações atorais se transformam em construtores da via estética. A experiência corpórea é que desencadeia o fluxo de imagens, de tensões e de palavras que atravessam a peça, criando uma pluralidade de vozes dissonantes que permeiam o contexto como parte do vivido, dialogando com os apontamentos da pesquisadora Cláudia Neiva Matos em que "a perspectiva da performance borra as fronteiras entre a aparente estabilidade do texto e a instabilidade do mundo e dos seres dos quais o texto provém e aos quais se dirige". ${ }^{10}$

$\mathrm{O}$ denominador desse pensamento coloca a dramaturgia como edificadora de um plano que estabiliza toda e qualquer materialidade capaz de fundamentar uma estrutura potencialmente expressiva, em que o corpo se solidifica, de fato, como instrumento e discurso, além de se constituir como o eixo dessa engrenagem performática de exposição e impacto.

\footnotetext{
${ }^{9}$ PAIS. O discurso da cumplicidade, p. 7.

${ }^{10}$ MATOS. Literatura e performance, p. 57.
} 
Barba defende a turbulência ou a revolta, no interior do processo dramatúrgico como algo essencial para a criação de uma ordem que não seja óbvia e ilustrativa, mas que tenha uma lógica autônoma, um caos de onde possa convergir a liberdade de escolher caminhos diferentes. ${ }^{11}$

Ao eleger a imagem como o princípio desencadeador do espetáculo, pontua-se um espaço experimental para o encontro dos dispositivos capazes de dar uma unidade identitária à peça, principalmente, no seu fluxo condutor que se apoia no jogo dos atores como conectores entre as paisagens criadas. A dinâmica desse fluxo passa a fazer parte do trabalho do dramaturgo, quando, então, é convocado a recolher essas conexões das improvisações nos ensaios. A mobilização dessas novas engrenagens sublinha um campo que experimenta novas formas de encadeamento de um espetáculo (que não passam pelo dramático), além de investigar como esses encadeamentos podem servir tanto como uma estrutura técnica de suporte da peça, quanto operar como sua via estética. A construção de tecidos interligados por fios invisíveis conectores perfazem uma dramaturgia que opera pela desdramatização de seus fundamentos. Ao estruturar o corpo e suas intensidades como motor dramatúrgico, a montagem insere o plano performático de sua gênese, fazendo com que a inserção dos corpos exerça a função de escritura pelos quais passam os discursos de impacto poético, político e existencial.

Estes campos heterogêneos que se abrem para a edificação dramatúrgica operam na reunião de sequencialidades, nas fisicalidades, nos subterrâneos e superfícies desveladas com as improvisações, nas partituras compositivas, no fluxo de movimentos, e, também, na memória e na história dos corpos que expandem a pessoalidade, expondo as fronteiras do coletivo ao transitar numa linguagem mutante, ao mesmo tempo irônica e poética. A ironia está presente em todo o espetáculo, desde as cenas construídas em cima de engradados de bebidas, passando pelo grito desesperado que os atores proferem quando a cena se fecha nas inúmeras overdoses acometidas pela geração (vícios, mídias, sistemas hegemônicos de opressão), até atingir o viés poético de quando um dos atores vai até o corpo desfalecido do outro e abre as nádegas do companheiro num gesto, ao mesmo tempo lírico e impactante, em que

${ }^{11}$ PAIS. O discurso da cumplicidade, p. 29. 
o nu passa a constituir uma escritura que se desenha nos incômodos do conservadorismo e da tradição.

Chamo a atenção porque, na descrição dos elementos discriminados acima, em nenhum momento convoquei termos como personagens, trama, coesão, ações, ou seja, o trabalho dramatúrgico incorpora outros expedientes e o rol de elementos em sua oficina se desloca para outros parâmetros de composição em que a ordem performática desestrutura os saberes convencionais e convoca para a construção de outras vias de sentido.

A música não é um elemento ilustrativo, mas atua como uma estrutura elementar que situa, desconstrói ou sublinha o corpus imagético. Os espaços e paisagens sonoros são criados como variáveis de um discurso poroso que convoca a livre associação de planos, evidenciando uma poética de contaminações mútuas, de obra em processo, de ruptura com as fronteiras do representacional, onde "criar a vida de um espetáculo não significa somente entrelaçar suas ações e tensões, mas também montar a atenção do espectador, seus ritmos, para induzir nele tensões, sem tentar impor uma interpretação." 12

Temos neste trabalho uma ruptura com o dramático expressa no caminho encontrado pelo diálogo interartes que assume uma frente de quebra com as chaves representativas, concentrando-se no que se pode reconhecer como "paisagens dramatúrgicas". ${ }^{13}$ Estas paisagens construídas conduzem para uma outra perspectiva de criação em que o universo visual é que deflagra a condução do espectador pelo percurso que se partilha. Dessa forma, a dramaturgia se concentra nas tensões físicas, na gramatura dos corpos, nas tensões plásticas apresentadas como contraste dos discursos que suspendem. A cada sequência são formadas paisagens que surgem e desaparecem de forma fluida, em consonância ou não com as camadas sonoras e os dispositivos projetados. Esta poética de imagens passa a escrever no espaço, textualiza o silêncio paralisante

\footnotetext{
${ }^{12}$ BARBA; SAVARESE. A arte secreta do ator, p. 70.

${ }^{13}$ Referência a um conceito utilizado pelo próprio dramaturgo na conferência Dramaturgia Contemporânea Portuguesa: as textualidades do século XXI, realizada no dia 26 mar. 2013, em Belo Horizonte-MG, da qual participei, que dialoga com a noção de peças-paisagens de Gertrude Stein, mas que, no seu caso, tem uma peculiaridade, já que o plano dramatúrgico trata-se de um desdobramento da sala de ensaio, e as paisagens respiram tanto a performatividade de sua inserção quanto a presença dos atores e do dramaturgo que as concebeu, evidenciadas pelo jogo cênico proposto pelo coletivo.
} 
do contemporâneo e compõe um mosaico de fragmentos invisíveis que coreografam o equilíbrio precário que a partitura atoral apresenta.

A dramaturgia parte de experiências vivenciadas pelos agentes criadores e se sustenta pelas imagens construídas, além de incluir algumas palavras projetadas e fontes textuais avulsas que atravessam o espetáculo numa sequencialidade tangenciada pela energia e movimentação dos atores, expediente que interpela sobre um jogo de livres associações das paisagens formadas em confronto ou como complemento das camadas sonoras e textuais. A linguagem do movimento e as correspondências entre o vivido e o inventado passam a constituir dispositivos escriturais que se debruçam nos corpos presentes como fontes geradoras dos códigos performáticos.

A linguagem verbal, nessa montagem, aparece muito pouco e quando aparece tem mais um efeito simbólico ou reflexivo sobre a encenação, o que acaba pontuando o ato improvisacional como linguagem, uma vez que são as relações estabelecidas pelos atores no palco que conduzem à constituição heterodoxa do trabalho. Texto e imagem não são necessariamente harmônicos nem complementares, criando, em muitos momentos, hiatos reflexivos que atualizam e presentificam os discursos. Essa vertente fortalece os estudos de Cohen ao reconhecer a cena contemporânea como um terreno plural de tensões estéticas, conduzindo os espaços dramatúrgicos pela noção reconfigurada que identifico como própria de um performer, reflexo dos desdobramentos que o texto passa a ter nessa rede performática de construção:

Em muitos casos, o texto estará sendo utilizado muito mais pela sonoridade que pelo seu conteúdo (utiliza-se o texto enquanto significante e não significado). [...] Em alguns casos o texto chega a se transformar num texto paisagístico, adquirindo características de cenário, como uma cor, uma luz ou em efeito especial: ele é transmitido simultaneamente com uma série de outras coisas, compondo um todo da mise en scène, sem haver, ao mesmo tempo, uma preocupação essencial com sua intelecção. ${ }^{14}$

O texto é fruto de um trabalho dramatúrgico contínuo, cujo motor suspende a generalizada crise que assolou a nação portuguesa e que

${ }^{14}$ COHEN. Performance como linguagem, p. 68. 
desencadeou uma manifestação popular na praça, situada em frente ao principal teatro da cidade. Na entrevista intitulada "Em crise política e existencial", concedida ao jornal O Tempo, em 29 de março de 2013, em razão da apresentação da peça em Belo Horizonte-MG, Oliveira destaca o trabalho de reescrita e das versões que o texto vai ganhando em razão dessa nova perspectiva:

$\mathrm{Na}$ origem do espetáculo, alguns textos traziam narrativas de jovens que queriam emancipar-se da sociedade - e, ao mesmo tempo, aniquilá-la. Nessa nova versão, optamos por tirar esses discursos, propondo outros que articulam diretamente as ações físicas que acontecem antes, depois ou mesmo simultaneamente a esses textos. ${ }^{15}$

Na curta temporada do Colectivo 84 realizada em Belo Horizonte, ${ }^{16}$ na sede da Cia Pierrot Lunar, essa questão ficou mais evidente quando, no intervalo de um dia para outro, o dramaturgo reescreveu o texto para a próxima apresentação, introduzindo, acrescentando e potencializando determinadas partes, fruto do entendimento cabal de que dramaturgia é um espaço construtor de experiências ou de práticas continuadas que dilata o conceito de escrita para o palco.

Desse modo, temos uma variante em que a função do dramaturgo não se encerra com a estreia do espetáculo, já que continua em processo e se modifica a cada apresentação, conforme os reflexos e desdobramentos do local e das circunstâncias onde é apresentado. Trata-se de uma dramaturgia escrita a partir da pulsão determinante que os integrantes do grupo alternam, contrastam, duelam e se traduz, obviamente, em uma provocação à fixidez textual imposta pelos modelos convencionais. Essa extensão da função do dramaturgo o coloca no centro das articulações do espetáculo em repertório, integrando sua função a uma certa presença, cuja atuação se expande para várias frentes, vias e dispositivos diferentes do arcabouço tradicionalmente conhecido como pertencente ao dramaturgo.

Além de trabalhar com a questão da dramaturgia viva e da presença in loco do dramaturgo, essa vertente opera exatamente na tensão

\footnotetext{
${ }^{15}$ OLIVEIRA. Em crise política e existencial.

${ }^{16} \mathrm{O}$ espetáculo foi apresentado em Belo Horizonte nos dias 29 e 30 de março de 2013 , na sede da Pierrot Lunar. Após as apresentações em BH, o grupo também realizou uma curta temporada no Rio de Janeiro.
} 
que se cria entre o limiar crítico que enreda e o eixo performático que desestabiliza noções categóricas. Assim, dramaturgicamente, criam-se zonas de indeterminação, modificações espaciais que se concretizam através dos corpos e seus estados rítmicos e, também, tensões no plano externo e interno de suas correlações. Notoriamente, a função dramatúrgica se redimensiona e passa a ser considerada não mais como receptáculo e sim como percurso.

Há um deslocamento pontual nos desdobramentos desse trabalho baseado no fluxo imagético que é o de convocar o público a pensar a obra por meio de imagens, tomando as paisagens criadas como sentido, forma e resultado do processo criativo. Essa forma de compor provoca leituras, cujo fluxo de significações acontece pelo modo como a dramaturgia é montada e pela dialética que se funda a partir dos campos que se tensiona. $\mathrm{O}$ valor crítico e os elementos usados têm uma natureza heterogênea e a dramaturgia evidencia a mobilidade de suas fronteiras com corpos atravessando palavras e palavras sendo escritas pelos corpos ou projetadas por eles.

Desse modo, cria-se uma obra constituída por atravessamentos que remetem ao caos contemporâneo, à cultura de excessos e à sexualidade como reflexos da ausência e do excesso de si, segmentos explorados em toda a peça que enredam espaços, instâncias, abismos e corpos. O repertório de partituras encontra as ressonâncias entre os sistemas gerados e o gerador, evidenciando a sua natureza heterogênea e o atravessamento dessas multiplicidades que amplificam o leque dos pontos de subjetivação, corroborando, no caso, com o prospecto de uma tessitura dramatúrgica em que a imagem passa a constituir uma escritura performática, que presentifica politicamente a peça no seu contexto.

\section{Referências}

BARBA, Eugênio; SAVARESE, Nicola. (Org.). A arte secreta do ator: um dicionário de antropologia teatral. São Paulo: Hucitec/UNICAMP, 1995.

COHEN, Renato. Performance como linguagem. São Paulo: Perspectiva, 1989.

COHEN, Renato. Work in progress na cena contemporânea: criação, encenação e recepção. São Paulo: Perspectiva, 2004. 
COLECTIVO 84. Disponível em: <http://colectivo84.blogspot.com.br>. Acesso em: 13 jul. 2017.

FERNANDES, Sílvia. Teatralidades contemporâneas. São Paulo: Perspectiva, 2010.

FERRARI, Anderson; CASTRO, Roney Polato de. (Org.). Política e poética das imagens como processos educativos. Juiz de Fora: Editora UFJF, 2012.

MATOS, Cláudia Neiva de. Literatura e performance. In: CARREIRA, A. L. A. et al.(Org.). Mediações performáticas latino-americanas. Belo Horizonte: FALE/UFMG, 2003. p. 49-58.

MONTEIRO, Rui. Crítica: horror ou breve estudo sobre a paralisia. Time Out, Lisboa, 3 set. 2011. Disponível em: $<$ http://colectivo84.blogspot. com.br/2009/04/press-entrevista-de-nuno-markl-john.html>. Acesso em: 12 set. 2013.

OLIVEIRA, Mickaël de. Dramaturgia portuguesa contemporânea (19742004): as teatralidades do século XXI. 2012. 227 f. Tese (Doutorado em Estudos de Teatro) - Faculdade de Letras, Universidade de Lisboa, Lisboa, 2012.

OLIVEIRA, Mickaël de. Obra completa. Portugal: Humus, 2015. t. 1: 2006-2014.

OLIVEIRA, Mickaël. Em crise política e existencial. O Tempo, Belo Horizonte, 29 mar. 2013. Cultura, p. 1. Entrevista.

PAIS. Ana. O discurso da cumplicidade: dramaturgias contemporâneas. Lisboa: Colibri, 2004. 